\title{
Introduction to Law as Plural Phenomenon: Confrontations of Legal Pluralisms
}

\author{
Wibo van Rossum \& Sanne Taekema
}

The traditional and dominant view among lawyers is that law is a system and that it originates with the state. Today's contrary view among some lawyers and a host of researchers from other disciplines says that law is plural in form and in source. Both views seem to rule each other out, seem to speak different languages, differ in assumptions and assign different normative tasks to law. Legal pluralism is the topic of this special issue, addressed in different ways, from different theoretical perspectives and in different empirical contexts. The first two articles in this special issue make clear that the debate over law as a plural phenomenon firstly bears a civilizing historical trait, and secondly has an ethnocentric component. Both articles make clear why many lawyers have a problem with viewing law as plural.

In the first article, 'Imagining the Rule of Law in Nineteenth-Century Britain: Liberal Society and the Dialectic of the Clan', Marc Weiner presents a cultural-literary-legal history of the transformation of law, society and imagination from 'the rule of the clan' to 'modern liberal law'. Weiner shows how the modern legal system or 'the liberal rule of law' as he calls it, in the nineteenth century wrestled itself loose from a situation of legal pluralism. In the previous period 'the clan' ruled; each in-group had its own rules, be it medieval cities, feudal lords and their servants, the church, guilds, etc. ${ }^{1}$ In the nineteenth century, due, among other factors, to growing state power, the need to govern the increasing population, and the upcoming ideology of the nation state, a national system of law needed to be constructed. ${ }^{2}$ Weiner shows how this was done by reinterpreting the plural legal past as constraining individual freedom, as arbitrary and as a source of social disorder, while at the same time as the authentic source of common law's progressive historical development. In other words, in nineteenth century Britain the modern liberal rule of law focused on the individual was constructed in contrast with and necessarily tugged out of the disorder of an arbitrary legal pluralism in which each order focused on collective processes.

In the second article, 'How Law Manifests Itself in Australian Aboriginal Art', by Agnes Schreiner, ethnocentric assumptions about law come to the fore. Schreiner uses two exhibitions at the Utrecht-based Aboriginal

1. See also B.Z. Tamanaha, 'Understanding Legal Pluralism: Past to Present, Local to Global', 29 Sydney Law Review (2007); St. John's Legal Studies Research Paper No. 07-0080. Available at SSRN: <http://ssrn .com/abstract=1010105>.

2. See also P. Fitzpatrick, The Mythology of Modern Law (1992).
Art Museum to state her argument. The modern, Western view of separating law from art (and any other 'discipline') guarantees a hard time of understanding the Australian Aboriginal view on law. Australian Aboriginal law is 'presentiated', she says, through art, and singing stories, and ritual dance: 'to make or render present in place or time, to cause to be perceived or realized as present'. Schreiner argues that a ritual dance makes law present, that paintings - even if temporarily in the sand - make law present, and that law in its turn causes the land to be present (literally: the land is sung into existence). Is that still 'law', we may ask, and by posing that question we show our ethnocentric position of hardly being able to understand law manifesting itself in any other form than as abstract, systematic, rulecontaining, socially distinct order backed up by state power. Law as plural phenomenon apparently can be disorderly, collective-focused and arbitrary, but also art, song and ritual. Modern law, however, is the negation of all that. That is why modern law stands in a tense relationship with legal pluralism. Should we confine ourselves to a narrow definition of law that developed historically in the West even when we seem to exclude many existing manifestations of law on our globe?

Emmanuel Melissaris, in the third article called 'From legal pluralism to public justification', tries to find a concept of law that solves the tension exposed by legal pluralism. He formulates what he calls 'by and large a socio-theoretical conception of law' that is very open to the normativity of social groups. He proposes to consider as law the sets of rules on which the belief converges that these should be followed. People in certain groups should be able to rationally and reasonably accept these sets of rules, and if so, these sets should then be considered legitimate. The exact substance of these sets of rules should be left to the political field.

Looking back at Schreiner's argument, the focus on rules as peculiar for law maybe excludes much of indigenous and aboriginal law. Melissaris' further argument, however, may find the appreciation of Weiner and probably Schreiner. He argues that sets of rules of groups or communities are closed, are inaccessible by people outside of that group. ${ }^{3}$ Non-participants are not able to share the insights of groups they are not insiders to (or only a little, because communication may give 'some understanding'). This resonates implicitly with Weiner, whose 'transition' in the nineteenth century seems to

3. Reminiscent of N. Luhmann, Das Recht der Gesellschaft (1995) 
have as consequence that it is hard to go back to a previous way of appreciating law. It resonates explicitly with Schreiner, since she argues that we can understand Australian Aboriginal law only when translated and transformed into familiar Western concepts. Since Melissaris constructs forms of law on the same measuring rod ('all law consists of rules'), understanding is theoretically possible (even if difficult, and only partly, he contends). Schreiner argues, however, that Australian Aboriginal law differs incommensurably from European styles of law. She would perhaps argue that in order to start understanding Australian Aboriginal law, one should perform a ritual, or paint.

The above sketch and summaries of the main arguments of the first three authors show part of the puzzle of today's concept of legal pluralism. We do not pretend that we can complete the puzzle; with this special issue we have gathered together important pieces to which other insights still need to be added. Even though the idea of legal pluralism has been with law and the sociolegal sciences explicitly since the beginning of the 1970s, it still challenges us (maybe that is its main reason of existence). In the 1970 s it was put forward as 'the' concept for understanding the social working of law in morally and socially plural societies. It was 'devised' to counter the idea that all law was created by the state. Especially John Griffiths, then one of the advocates of legal pluralism, critiqued the ideology - as he called it of legal centralism. ${ }^{4}$ In his view, law originated from below, in groups and organisations in society. The concept of legal pluralism was also developed, albeit rather implicitly, in order to 'emancipate' the indigenous peoples in the (ex) colonies and later also the ethnic minorities in Western Europe and the USA. When you stretch the traditional concept of positive law, also dominant among lawyers, and discard the requirement that law is a 'state thing', then indigenous peoples and ethnic minorities can have 'law' too - even if that law is different from state law and not codified. That move circumvented the accusations of law's ethnocentrism. The third, rather implicit, goal of the concept of legal pluralism was to open jurists' eyes to the social reality of law. Jurists - the message was - need to pay attention to the empirical reality of law, to lam in action aside from lam in the books.

The concept of legal pluralism encountered scepticism and resistance right from the beginning. As soon as it was stated as a 'problem for law' or as a 'new paradigm for the study of law', its promoters were asked to define it. This was problematic. Legal pluralism could not be pinned down in a single definition, because it turned out to be either too narrow or too broad, while at the same time empirical definitions stood crosswise at normative definitions. It could be defined as a social field, as a normative paradigm, or as a factual situation to be described, but with each definition something was left out that according to researchers should still be included, or the definition was too wide to be of any analytical use. ${ }^{5}$ Thus, legal pluralism was sometimes firstly used as a descriptive container concept by including all social rules - and hence became meaningless for the study of law. Sometimes, and secondly, the concept of legal pluralism was used in ways that put all kinds of ordering on an equal footing normatively - as if from a philosophical point of view the Universal Declaration of Human Rights could just as well be traded off with any local form of customary law. Or to the contrary, the definition held implicitly that state law should be the norm to judge all other law. Thirdly, some scholars tended to forget strategy and pomer issues, as if questions of dominance and subordination of legal systems (empirically and normatively) were merely descriptive matters or left to philosophy to think about - while the question of the dominance of one type of law over the other of course also depends on which players in society have the best resources, more money, more proponents, better access to the media etc. These factors influence how different legal systems interact and what the results will be in terms of a specific mixture of a plurality of laws, and of rules in one set influenced by rules or concepts from another system.

Empirical research into actual situations of legal pluralism has shown that 'on the ground' the interactions and clashes between legal systems and forms are easily recognised. Law practitioners and lay people cope in, and with, those situations, and they know how power and politics, morality and behavioural routine interfere with the validity of diverse legal phenomena. The paradox is that theoretically inclined researchers so far have not been able to demarcate the field of study analytically. Some researchers even concluded that there is 'no progress' in the theory of legal pluralism. ${ }^{6} \mathrm{We}$ tend to agree with that conclusion, and we see it as inevitable, not as a problem. Legal pluralism did not turn out to be the new general theory of law, because first it is not a theory but a perspective, and second because a unified general theory of law is impossible to formulate. Law is a diverse and plural phenomenon, and therefore theories of law are pluralistic, and we need to theorise how they should relate to one another.

In addition to the three theoretical contributions on how to view legal pluralism historically, culturally and theoretically, we have three more contributions in this special issue that each in their own way analyse a plural situation and from that perspective hope to contribute to a theory on how to relate plural legal phenomena. The three 'cases' are all very different. The article by Ronald Janse, 'A turn to legal pluralism in rule of law promotion?' deals with the often-encountered problem of NGOs and monetary agencies in developing countries, where the implementation or furthering of the rule of law is frustrated by local situations where people prefer 'their own law and procedures'. Janse analyses why it is so difficult to take local legal forms into account, basi- 
cally arguing that the ideology of state-centred, uniform, non-personal abstract legal system is the largest barrier to developing a workable situation. Lawyers simply assume that non-state law is basically the same as state law, only not codified and not enforced by state authorities. Moreover, their normative assumption is that state law should be the legal system that regulates the existences of non-state law, in other words that state law is rightfully the dominant set of rules. These assumptions and expectations lead to the conclusion that rule of law and legal pluralism is not a very happy marriage.

The next article covers a situation closer to the home of the ordinary lawyer. Urszula Jaremba, in her contribution 'At the Crossroads of National and European Union Law; Experiences of National Judges in a Multilevel Legal Order', describes empirically how Polish, German and Dutch civil law judges do or do not take account of European legal rules. And for this multilayered legal order to work, the first thing judges simply need is knowledge. The judges who were surveyed and interviewed made clear they do not encounter European law very much in their daily work, they do not know much about it, they do not feel they are well equipped, and it takes too much time to delve into it. The consequence of this is that these civil law judges tend to evade even contemplating applying European legal rules in national civil law cases. Although doctrine states that European law is part of the national law of the European member states, for these judges it appears as a foreign system, which they prefer to leave alone.

The final 'case study of legal pluralism' takes us to the Middle East, to Syria in particular. Esther van Eijk in her article, 'Unity in Multiplicity: Shared Cultural Understandings on Marital Life in a Damascus Catholic and Muslim Court', describes in detail and analyses how different religious family laws are applied in courts while under the patronage of a state legal system that leaves them room to do so. It makes for an interesting situation. Van Eijk argues that even though Syrian state law leaves room for the application of Catholic and Muslim family law and these laws differ in important aspects, the underlying social rules on marriage and gendered roles among Catholics and Muslims have much in common. In other words, a plurality of formal law should not blind us to a shared social normativity.

Theorising a little further on how a plurality of laws should be conceptualised in a framework that does justice to each of them, we think the following elements can be gathered from the collected articles in this special issue, which merit further thought. The first three articles open up space to a more inclusive approach of the multiple forms law manifests itself. The sociolegal point of departure could be a conventionalist approach to law (law is what certain social groups conventionally call law). We should remember that our present concept of law as systematic and tied to the power of the state is the result of a contingent historical development that is not necessarily universal. This does not mean, however, that we need to give up our concept of law, but neither should we discard other concepts as irrelevant or 'not up to modern standards' beforehand.

The next question is how to deal with this plural legal situation normatively. We opt for a pragmatic approach and formulate three basic requirements. The first requirement can be derived from the article by Janse on furthering the rule of law in developing countries, in line with what we said above. We should oppose the automatic notion that Western systematic and codified law is the best and most developed law there is. Arrogance has no place in a globalised world. That is not to say we need to be humble. Western law has certain advantages like legal certainty, the principle of equality, the ideal of the rule of law, etc. We should stress these advantages in local and global argumentative arenas.

A second necessary step, which becomes clear from the work of Jaremba, is knowledge dissemination. Without knowledge of other forms of law, especially those legal professionals and other actors who work with the dominant set of rules will not be able to give law a legitimate meaning. Similarly, people working with less-known concepts of law should have knowledge of other legal phenomena.

The third aspect, deduced from Van Eijk, is that we should not forget that law in books and law in action are not two sides of the same coin. They may differ considerably. In situations in which a minority people press or ask for respect for 'their own law', it could be that the demand is partly political, part of power struggles in the group or deemed important for developing a distinct identity. The actual interpretations of the rules and their social implications may well be very close to those of the dominant group. Two different laws in books (belonging to two different legal orders) may very well have quite similar laws in action.

In summary, our three elements to further theorise how to deal with legal pluralism in a pragmatic and normative sense are that actors should argue openly and without prejudice that they should have wide knowledge of different forms of law, and that they should realise that however well designed a legal regulation may be, the empirical reality on the ground may find its own and at times unexpected form.

Even though this special issue on legal pluralism is necessarily diverse in approaches, disciplines and empirical grounding, we feel we have taken two steps forward in looking at law as a plural phenomenon. Maybe we now need to take one step back, but that would still mean progress. 